DOI: http://dx.doi.org/10.18290/rh20689-5

\title{
CONSTRUCTING A MORAL PERSON IN THE ANALECTS 論語 AND MENGZI 孟子*
}

\begin{abstract}
A b stract. In early Chinese philosophy, the concept of a unique individual separated from the outside world has no ontological basis. Every person is an open, interdependent construction, whose uniqueness can only be achieved and cannot be given. A person is an undetermined range and locus of experiences expressed through specific roles and relationships. In this article, the Author analyses such an understanding of the person in Confucian and Mencian thought. In Confucius' philosophy, the junzi 君子 lives up to his status as long as he maintains ren 仁 relationships and displays proper emotions connected to ren. The author argues that, in the Analects, ren is a concept connected to the terms $s h u$ 恕, zhong 忠, $y i$ 義 and $l i$ 禮. Ren may be interpreted as an ideal interaction that starts with an emphatic reaction towards another human being. Emphatic reactions, along with zhonga sense of duty - is the basis for applying the situational moral norm $y i$ and carrying it out according to $l i$ - the social norm. Ren behaviour is different for every person in every situation. It has to be learned and practised during the process of self-cultivation, xiushen 修身.

Mencius' moral theory is more complex, and concentrates on human nature and its features. According to this, human nature is shan 善, commonly translated as 'good,' because every person has four dispositions - emotions for developing ren, yi, li and zhi 智. Ren may be considered a virtue - it is not inborn, but has to be achieved and learned. Another skill required to be a sage was the understanding that every situation is unique, and that there is a right time to apply different norms - shizhong 詩中. Mencius' thought is not simply an ethics of virtue, but it is also influenced by situational factors. Mencian moral behaviour is complex; not only does it require a deep understanding of oneself and the other, but also the use of all senses, sensitivity and creativity to deal with every situation in a different way. A sage, or a person who wants to become one, has to watch, listen, feel and understand every person and every situation. Moral cultivation in Mengzi's thought is also a cultivation of the body's $q i$ 氣 (vigour or energy). Properly cultivated $q i$ becomes haoran zhi qi 浩然之氣 (overflowing $q i$ ) and enables one's body to have the $z h i$ 志 (will) to follow its ren (heart / mind).
\end{abstract}

Key words: Chinese philosophy; moral theory; ethics; moral behaviour; Confucius' philosophy; Mencius' thought.

Katarzyna Pejda, PhD - John Paul II Catholic University of Lublin, Faculty of Humanities, Department of Sinology; e-mail: katarzynapejda@gmail.com. ORCID: https://orcid.org/0000-00033091-0534.

* This paper is based on a talk given at ISCP $21^{\text {st }}$ International Conference on Chinese Philosophy held at the University of Bern on July $2^{\text {nd }}-5^{\text {th }}, 2019$. 
In early Chinese philosophy the concept of unique individual separated from the outside world has no ontologicał basis. Every person is an open, interdependent construction whose uniqueness can only be achieved, not given. Confucian philosophers perceived the human being as an undetermined range and locus of experiences expressed through specific roles and relations (Geaney 113-142). The notion of the interdependent self is articulated most clearly in a relational ethic. Self-cultivation, one of the major themes in early Confucian philosophy, focuses mainly on acquiring skills in balancing competing demands, loyalties and obligations. Aspects of relationality are morally important, thus moral deliberation is not driven ultimately by consideration of value, rules or correct application of principles. The fundamental concern in Confucian ethics may briefly be described as the application of right action by cultivated individuals who are aware of their relational commitments and status, hence development of self is a complex process within particular contextual and relational boundaries (Lai, "Confucian Moral Thinking" 249-272). In Confucian thought, the agent of conduct is not separated from the conduct itself; as Rosemont puts it, he is a flesh and blood role-bearer (Ames and Rosemont 8).

Western philosophy considers reason superior to virtue, claiming that knowledge is the prerequisite to virtue, and where there is knowledge, there will be virtue. Chinese philosophy holds that virtue is superior to wisdom. Thus intelligence does not intend to pursue the truth, but is meant to look for what is proper, to discern right from wrong (Quanxing and Deyuan 39-54). Therefore, Chinese relational role ethics emphasizes improving the cognitive subject. Achieving moral integrity, and consequently wisdom, is a main objective of self-development in early Confucian thought. Moral development lasts as long as a person lives: it is a day-to-day struggle. Confucian ethics is role ethics; Confucian self-development could also be described as growing into one's social role and perfecting relations with other people (Ames and Rosemont 12). All mentioned views are prominent in Analects and Mengzi alike.

I also argue that in both texts self-refinement of character was considered a main activity for any person who aspired to become an exemplary person junzi 君子. I also examine a meaning of ren usually translated as "humanity," "benevolence". I claim that in Analects ren is a concept cluster connected to several other concepts, such as empathy shu 恕, sense of duty $z h o n g$ 忠, moral norm $y i$ 義, and social norm $l i$ 禮. Ren in Analects could be interpreted as a harmonious relation with others, while in Mengzi ren is a trait of character extended from one of four dispositions si duan. 
Although views on human nature are not prominent in the Analects, Confucius was certainly optimistic about human ability to learn how to behave properly. Restoring the harmony he 和 of the First Kings xianwang 先王 was possible only when society was ruled by a morally perfect person, an exemplary person junzi 君子. Confucians claimed that people could become morally perfect if they set their will zhi 志 on following the dao 道. Ability to become a junzi suggests that there is an innate disposition toward goodness in every person and, as Ames puts it, "person making was an open-ended activity" as dao is not a "predetermined objective path" and every human may add value to the dao (Lunyu XV.28). Every person had a potential for selfdevelopment, as sky/heaven tian 天-endowed disposition de 德 was a possible justification of that view. As the ultimate purpose of the junzi was to build a harmonious society, self-cultivation was to be realized within society.

There are two important remarks on the proper order of self-improvement in the Analects:

The Master said: "At fifteen I set my heart on learning; at thirty I took my stand; at forty I came to be free from doubts; at fifty I understood the Decree of Heaven; at sixty my ear was attuned; at seventy I followed my heart's desires without overstepping the line." (Lau, trans., Confucius. The Analects 63)

子曰: “吾十有五而志于学, 三十而立, 四十而不惑, 五十而知天命, 六十 而耳顺，七十而从心所欲，不逾矩。”(Lunyu II.4)

and

"I set my heart on the Way, base myself on virtue, lean upon benevolence for support and take my recreation in the arts" (Lau, trans., Confucius. The Analects 86)

「志於道, 據於德, 依於仁, 游於藝。」(Lunyu II.6)

At the initial stage of self-improvement the activity of xue 學 or "learning" depended largely on reading ancient texts such as the Odes Shi Jing 詩經 or Rites Shu Jing 書經. It served two purposes: learning the language so that one could speak properly (Lunyu XVI.13) and acquiring historical knowledge about noble rulers - Former Kings, who followed the dao, setting the example of ideal governance. Social standing or public stance could transform the world; consequently, public interests were more important than private ones. "Taking a stand" meant selflessly fulfilling one's role in society. Being a public figure required understanding what Heaven expects one to do tian- 
ming 天命 and following one's dao (Lunyu VII.22, IX.5, XIV.35). Apparently all of the senses were engaged in the process - a person had to "attune their ears" or become sensitive to what is proper. Confucius looked for moral guidance beyond the world of people, considering sky/heaven tian as the source of order. Sky/heaven tian as a mute guide, led people by setting an example of proper order that prevails in the world. It was also a source of a moral disposition, de, commonly translated as "virtue". In Western philosophy, by contrast, virtue is typically not inborn, but has to be learned or achieved.

Cultivation of self is cultivation of relationships, it is development of self in the social environment (Lai, Learning from Chinese 33). That understanding of self underlies the subsequent interpretation of ren 仁 and its root xiao 孝. In Xiao Jing 孝經, a text by Confucius' disciple Zengzi, human emotions are an important part of moral teaching: "for teaching the people to be affectionate and loving, there is nothing better than filial piety" (教民亲 爱, 莫善于孝) (Legge, trans., Xiaojing). In the Analects, xiao is portrayed as obedience and caring for one's parents according to prescribed norms $l i$ while they live (Lunyu II.5), and after death, proper burial, sacrifices and three years' mourning. Xiao is associated with respect (jing 敬), as proper deeds must be carried out with proper affection (Lunyu II.7, II.8, XVII.21). Relations inside the family constitute the pattern of behaviour outside the family - the junzi serves parents and shows respect at home as he serves and respects superiors. Xiao is indispensable to further ethical development; it is the root of ren (孝弟也者, 其為仁之本與) (Lunyu I.2).

Etymological analysis of the Chinese character ren ("standing man" on the left side of the character and "two" on the right) suggests that the concept pertains to "human relatedness" (Lai, Learning from Chinese 15). Shuowen Jiezi identifies ren as qing, feelings between people. Ren is mentioned in fifty-eight passages, lacking a proper definition due to the fact that explanation of this crucial term depended on the intellectual ability of the student who asked about ren; hence many aspects of ren are mentioned. The meanings of ren and ideas most relevant to my analysis are:

- “[Ren is] to love your fellow men" (樊遲問仁。子曰：愛人。) (Lunyu XII.22).

- A person who possesses five features could be described as ren, "they are respectfulness, tolerance, trustworthiness in word, quickness and

${ }^{1}$ Ai ren 愛人 means „to love people, who are not your kin”, while qin 親 means „to love your own kin" (Lau, trans., Confucius. The Analects 116). 
generosity" (Lau, trans., Confucius. The Analects 116-117) (孔子曰: 能行五者於天下, 為仁矣。請問之。曰: 恭、寬、信、敏、惠 $)$ (Lunyu XVII.6).

- One needs the society of worthy people to be ren or to become ren (里 仁為美。/居是邦也, 事其大夫之賢者, 友其士之仁者。) (Lunyu IV.1, $\mathrm{XV} .10)$.

- "The ability to take as analogy what is near at hand (oneself) can be called the method of ren" (Lau, trans., Confucius. The Analects 90) (能 近取譬，可謂仁之方也已。)(Lunyu VI.30).

Ren can be interpreted as moral integrity in its normative meaning, a moral ideal manifesting itself in relations with other people; one feature of human character was not enough to decide whether a person could be considered ren (Lunyu V.7, V.18, XIV.1). Also, as Ames points out, "ren is not a specific virtue that can be named and analytically isolated as defining of one's character any more than what it means to behave in a consummately humane way can be stipulated and replicated without reference to specific roles and situations" (Ames and Rosemont 114).

The interdependent or relational Chinese self may be fully realized within a network of relations. It is not viewed as an independent entity, so the dichotomy of self and society does not exist (Lai, "Confucian Moral Thinking" 249-272). Confucius' ethical theory is based on a careful observation of society and its relations. The aim of ren behaviour is to transfer family emotions to other people - hence the meaning "to love fellow men." The practical dimension of ren, the ability to take as analogy what is near at hand (oneself), allows one not to impose on others what he himself does not desire (己所不欲, 勿施於人。). Shu 恕, empathic reaction towards other people, a guide to conduct throughout one's life (Lunyu XV.24) is the essence of ren behaviour. In passage IV.14 shu 恕 is mentioned together with zhong 忠 as Confucius speaks about a single thread that binds his dao (夫子之道，忠恕而已矣。). Zhong 忠，traditionally translated as "loyalty， doing one's best," may also mean "a sense of duty" bound to a person's status. Minister Zi Wen, mentioned in passage XV.19, not only did not give the appearance of displeasure when removed from office, but also informed his successor what he did during his term of service, showing himself to be a dutiful servant. Loyalty and sense of duty, the feeling of obligation, follows empathic reaction toward others (Lunyu V.19). Zhong 忠 is mentioned five times with xin 信 in a phrase zhu zhongxin 主忠信 (Lunyu I.8, V.28, IX.24, 
XII.10, XV.5). Xin 信, as trustworthiness, living up to one's word, is closely related to zhong, as every person who follows his dao should honestly and without hesitation fulfil his duties. Xin is a match between how one presents oneself in interaction with others and whether one is in fact the person whom one presents oneself to be. It is also an essential human quality-someone without xin is like a carriage without a yoke, not able to function (Lunyu II.2).

$Y i$ 義, traditionally translated as "righteousness," is rarely connected to the concept of ren because it does not appear in "ren passages." However, in Xing Bing's 邢旵 commentary (論語注疏) on He Yan's 何晏 text (論語 集解) concerning the phrase keji fuli 克己復禮, we read:

Liu Xuan says, “ $K e$ 克 should be interpreted as 'to overcome'. $J i$ 已 means the individual. When the individual has cravings and desires, he should order them with propriety ( $l i$ 禮) and righteousness ( $y i$ 義). When one's cravings and desires do battle with propriety and righteousness, and propriety and righteousness overcome cravings and desires, then the individual returns to propriety. This then is ren. (Kieschnick, "Analects 12.1 and the Commentarial Tradition" 567-568)

劉炫云：“克訓勝也，已謂身也。身有嗜慾，當以禮義齊之。嗜慾與禮義 戰, 使禮義勝其嗜慾, 身得歸復於禮, 如是乃為仁也”。

Xing Bing claims that $y i$ is equally important as $l i . Y i$, usually translated as "righteousness", or as Lau puts it, "morality", appears in two important passages. $Y i$ is a measure of proper behaviour. Courage, for example, is perceived as good as long as it is used in a proper way ${ }^{2} . Y i$ is a method of measuring appropriateness of human qualities and deeds:

Zilu said: "Does the gentleman consider courage a supreme quality?" The Master said: "For the gentleman it is morality that is supreme. Possessed of courage but devoid of morality, a gentleman will make trouble while a small man will be a brigand." (Lau, trans., Confucius. The Analects 147)

子路曰: “君子尚勇乎? 子曰: 君子義以為上。君子有勇而無義為亂, 小人 有勇而無義為盜”。(Lunyu XVII.23)

Another meaning of $y i$ is depending on the situation rather than following strict external regulations:

\footnotetext{
${ }^{2}$ A similar method of valuing is described in Lunyu passage XIV.33: The Master said: “A good horse is praised for its virtue, not for its strength.” 子曰：驥不稱其力, 稱其德也.
} 
The Master said: "In his dealings with the world the gentleman is not invariably for or against anything. He is on the side of what is moral." (Lau, trans., Confucius. The Analects 68)

君子之於天下也，無適也，無莫也，義之與比 (Lunyu IV.10)

Apparently for Confucius, what was moral was not set in advance, there were no external rules of proper behaviour. Nevertheless morality has to be grounded, to a greater or lesser extent, in objective criteria, must possess consistency, impartiality, universality (Lai, Learning from Chinese 119). To maintain moral integrity and proper relations a person, as interdependent self engaged in many social roles, must have taken under consideration the will of sky/heaven (tian 天) expressed in order of sky/heaven (tianming 天命), natural order dao and personal status (ming 名).

Given all the information above, especially Xing Bing's commentary, it is possible to understand passage XII.1, which is usually the core of ren interpretation, as follows:

Limit oneself [to observing norms $(y i)$ ] and return to the observance of rites - [this is] maintaining relations (ren).

克己復禮為仁

It is quite clear that ren is a concept-cluster. Its full meaning is revealed in connection with other concepts present in the Analects: shu 恕, zhong 忠, $y i$ 義 and $l i$ 禮. From the sociological and psychological perspective ren may be described as an ideal interaction that starts with an empathic reaction towards another human. It is shu mentioned as a rule that should be practiced all one's life (Lunyu XV.23). Shu and zhong are starting points of any interaction, a basis to apply situational moral norms $y i$ and carry them out according to social norms $l i$. In a Confucian world, it is not possible to act properly without complete understanding of one's duties connected to one's social roles. To maintain moral integrity and proper relations, a person must take under consideration the will of heaven/sky tian expressed in its' order, natural order and personal status. Ren is rooted in xiao 孝, filial piety, respect and love towards one's kin and respect towards one's superior, as early Confucians claimed that a person is able to learn proper emotions and the best way to do that is to practice xiao. Ren behaviour is different for every person in every situation, "a cultivated virtuosity in role-specific dispositions that conduce to making any particular action optimally elegant and appropriate" (Ames and Rosemont 114). 
Ren behaviour can be learned during a process of self-cultivation xiushen 修身. Acquiring the ability to behave in a ren way was described as difficult and yet quite natural. Yan Yuan 顏, who was the Master's most talented pupil, was able to not lapse from ren behaviour for a long time, unlike others $^{3}$. Confucius noted that ren behaviour depended mainly on the act of will ${ }^{4}$. Yan Yuan described the vagueness of the Master's advanced moral instructions, suggesting that intuition might play some role in understanding the Confucian way:

The Master is good at leading one step by step. He broadens me with culture and brings me back to essentials by means of rites. I cannot give up even if I wanted to, but, having done all I can, it seems to rise sheer above me and I have no way of going after it, however much I want to. (Lau, trans., Confucius. The Analects 97-98)

[…] 夫子循循然善誘人, 博我以文, 約我以禮。欲罷不能, 既竭吾才, 如 有所立卓爾。雖欲從之, 末由也已 (Lunyu IX.11)

Moral cultivation based on acquiring norm $l i$ bears parallels with musical training (Lai, "Confucian Moral Cultivation" 107-139). For the beginner, technical competence is of the most importance - one strictly adheres to the rules. A "master musician", a junzi, on the other hand, focuses upon expressiveness in performance. The junzi has mastered the rules, and his heart does not desire what is not according to them一七十而从心所欲, 不逾矩 (Lunyu II.4). Mastering of $l i$ norms also played another important role in Confucius' morality - it helped to balance strong emotions such as grief and express them in a civilized manner. Emotions and natural affections towards others are considered basis of Confucian moral philosophy (Seok 55-56). The importance of them is already emphasized in Analects, but also in other early texts such as Zhong Yong 中庸:

Humanity means "human: cleaving to one's kin is its foremost element, Right means 'appropriate': honoring the worthy is its foremost element. The degree that govern cleaving to one's kin and the ranks that govern honoring the worthy are the things that give birth to ritual. (Eno, The Great Lerning)

仁者人也, 親親為大; 義者宜也, 尊賢為大親親之殺, 尊賢之等, 禮所生也

(Zhongyong 20)

\footnotetext{
${ }^{3}$ 其心三月不違仁 (Lunyu VI.7), “In his heart for three months at a time Hui does not lapse from ren" (Lau, trans., Confucius. The Analects 82).

${ }^{4}$ 仁遠乎哉? 我欲仁, 斯仁至矣 (Lunyu VII.30), “Is ren really far away? No sooner do I desire it than it is here" (Lau, trans., Confucius. The Analects 90).
} 
According to author of another classical text-Xiao Jing 孝經—-moral emotions could be taught by being obedient to one's parents (教民親愛, 莫 善於孝). The role of moral emotions became also crucial to Mencius ethics - it is going to be elaborated later in the text.

Confucius' morality is based on acquiring skills of proper behaviour; mastering those skills is within reach of any self-aware and others-aware individual (Lunyu I.4). The exemplary person, however, does not cultivate himself only for his own benefit. By practicing ren relations, the junzi helps other members of society in their self-improvement. The final goal of the society led by the junzi elite is to maintain harmony he 和 and rule according to dao.

There is an agreement that Mencius developed Confucius' vision of morality. It is far from true, however, that ren as a concept-cluster in the Analects is identical to the concept of ren in Mengzi's thought - a continuity is also a major shift from morality describing proper behaviour and skills in relations with others, to the realm of role ethics based on reflection on human nature. As Lau puts it: "there is no doubt that Mencius' philosophy is essentially based on the teachings of Confucius, though in some respects it developed beyond their limits" (trans., Mencius xi). Mencius evolved Confucius' idea that self-cultivation involved a realization of heaven-endowed heart-mind through the extension of compassion and concern for family members towards others outside the family (Lai, Learning from Chinese 6). Xin 心 is a pivot between human nature and body theory and ethical theory in Mencian philosophy, and possesses both - cognitive and emotive aspects; I will adopt the term "heart-mind" as a translation. Heart-mind xin appears in a set of moral dispositions (si duan 四端) that make human nature originally prone to be good, but which are not themselves enough to constitute a good nature. If not well prepared, a person will experience moral failure. As Cua puts it, "When our mind is not functioning properly, we make distinctions among myriad things and unreasonably place more value on one thing than another, thus leading to misconduct" ("Xin and Moral Failure" 143-44). Without using his or her heart-mind, a person was completely determined by desires, and desires depended upon their respective objects - without moral thinking a man did not differ from animals (Lau, trans., Mencius xv).

Human body had an integral role in achieving personal identity and consummate conduct, as the body is a process of collaboration between the person and the world, between organism and environment (Ames and Rosemont 13). Human nature may possess dispositions toward being a morally 
good person, but if moral development is neglected the sprouts will not grow. Lack of a fixed heart-mind and lack of will might led to lack of the sense of moral priority and lack of self-examination. To develop one's moral character one must achieve a fixed heart-mind (budong xin 不動心), or preserve the constancy of heart-mind hengxin 恆心. To attain a fixed heart it is necessary to cultivate bodily energy ( $q i$ 氣) and the will ( $z h i$ 志). Echoing Confucius' statement on his own development ${ }^{5}$, Mencius speaks of this mutual interdependence:

My heart has not been stirred since the age of forty $[\ldots]$

The will is leader of the $q i$, and $q i$ is something that fills the body. Wherever the will leads the $q i$ follows. Thus there is a saying, "Grasp your will and do not dissipate your $q i$ ".

[...] "Wherever the will leads the $q i$ follows", but you also said "Grasp your will and do not dissipate your qi"? Is there not inconsistency?

"When the will is unified it moves the $q i$. But when the $q i$ is unified, it can move the will. For example, when you see a man stumble or rush about, this is the action of his qi. In such cases, it has turned back upon the heart and moved it." [...] (Eno, "Mencius" 38)

孟子曰: ” [... 我四十不動心。」 $[\ldots]$

$[\ldots]$ 志, 氣之帥也; 氣, 體之充也。夫志至焉, 氣次焉。故曰: 『持其

志, 無暴其氣。』

『志至焉，氣次焉』，又曰『持其志無暴其氣』者，何也？

「志壹則動氣, 氣壹則動志也。今夫蹶者趨者, 是氣也, 而反動其心

(Mengzi II.A.2)

Since the human body is such an important factor in self-development, careful observation of the human body was also essential to estimating the character of a person:

"Nothing is better in examining a man than to observe the pupils of his eyes. They cannot conceal his faults. If he is upright within his breast then his eyes will be clear; if he is not, they will be murky. Listen to his speech, stare into his eyes where can he hide?" (Eno, "Mencius" 77)

存乎人者, 莫良於眸子。貽子不能掩其惡。胸中正, 則眸子瞭焉; 胸中不 正，則眸子眊焉。聽其言也，觀其眸子，人焉㢑哉？(Mengzi IV.A.15)

Physiological features and bodily expressions described in above-mentioned passage give away certain traits of human character. But they are not

5 四十而不惑 (Lunyu I.4), “At forty I came to be free from my doubts” (Lau, trans., Confucius. The Analects 63). 
only emotions that are important in Mencian moral theory. Mencius recognized emotions crucial to our moral judgement, development and actions.

The idea of the family environment as the soil from which grows a political and moral order was endorsed by both Confucius and Mencius. Hence the utmost importance of feelings toward the family qin 親 expressed in the Analects, Mengzi and Xiao Jing. To be human is to grow in an environment of family affections; that environment granted one the capacity to become increasingly human. Humans and their morality originate in the family - the cultivation of being a moral person starts and ends in a family context. As ren grows initially from a family, a noncoercive governing is possible or, as it is described in the Xiao Jing, "being effective without being strict," a society with family-like relations between rulers and subjects regulated by ritual and not by laws (Behuniak 89). Mencius observed:

"The substance of humanity is serving one's parents; the substance of right is obeying one's elders. The substance of wisdom is unswerving awareness of these two." (Eno, "Mencius" 79)

仁之實, 事親是也; 義之實, 從兄是也。智之實, 知斯二者弗去是也.

(Mengzi IV.A.27).

In Mencius' ethics xing was dynamic and relational term referring to a creative act rather than to something that was given. Thus interpreting Mencius' words as "nature is good" and there is no need for further nourishment yang 養 is not entirely correct. The phrase "human nature is good, just as water seeks low ground” (人性之善也, 猶水之就下也) (Mengzi VI.A.2) clearly shows that human nature is prone to be good as long as it does not encounter any obstacles and dwells in a correct place:

"Only a gentleman can maintain a constant heart without constant means. For the common people, if they have no constant means of support, they cannot sustain their hearts' resolve. Without the constant resolve of the heart, they will slip into excesses and deviant behavior, stopping at nothing." (Eno, "Mencius" 25)

無恆產而有恆心者, 惟士為能。若民, 則無恆產, 因無恆心。荷無恆心 放 辟，邪侈，無不為已. (Mengzi I.A.7)

Mencius spoke of the goodness (shan 善) of human nature, because he claimed that people possess the ability to pity other beings - not being able to bear (bu ren 不忍) the suffering of an ox, or experiencing the spontaneous urge to help a child in imminent danger. Since distress while seeing other 
beings in danger is a sprout of ren, developing the human capacity to inflict no violence is as natural as water tending to flow downwards. In early Confucian tradition, moral development traces back to affections that one shares with parents, and becoming "sage-like" means developing one's initial dispositions: congenital feelings of pity or compassion, shame, modesty and the ability to tell what is proper and what is not:

"The sense of commiseration is the seed of humanity, the sense of shame is the seed of righteousness, the sense of deference is the seed of ritual, and the sense of right and wrong is the seed of wisdom. Everyone possesses these four moral senses just as they possess their four limbs." (Eno, "Mencius" 44)

惻隱之心, 仁之端也; 差惡之心, 義之端也; 辭讓之心, 禮之端也; 是非之 心，智之端也。人之有是四端也，猶其有四體也. (Mengzi II.A.6)

Mencius is indeed a faithful student of Confucius as he also recalls the importance of empathy and the silver rule. While human being at birth possesses everything that is needed to become a moral person, he or she must develop moral sense self-examining himself, checking whether he or she was true to the original sky / heaven tian endowed nature:

"The world of things is complete in me; to reflect upon oneself and find perfect integrity: there is no joy greater than this! To strive to act with reciprocity [or empathy, K.P.], there is no closer approach to humanity." (Eno, "Mencius" 124)

孟子曰: “萬物皆備於我矣。反身而誠, 樂莫大焉。強恕而行, 求仁莫近 焉.” (Mengzi VII.A.4)

The main target of ren is being able to feel what other beings feel in immediate danger (ox), being able to imagine how another human would feel if something bad has happened to their child (the child and the well), or simply being able to put oneself in other people's place $s h u$, and to do that in each situation in which moral imagination is required. Together with the sense of shame that prevents one from transgressing social norms, and modesty about behaviour, the picture is painted of ethics as caring more for others' well-being than for one's own freedom and autonomy. Ren is no longer a concept-cluster, the ideal relation between two people as in the Analects, but one of four qualities of moral character that a person who wants to be described as human should possess. If one wants to remain human, one must maintain and extend the feelings or dispositions that makes one a human being. 
The aim of self-development was to cultivate or, as Mencius puts it, extend particular moral feelings - the sprouts - into constant traits/qualities of moral character. The basic moral feeling is recognized by means of selfexamination, it is followed by reflection on human nature and cultivation that engages rational and intellectual capacities. As the sprouts extend and turn into a permanent traits of character - ren, yi, li and zhi-then one's moral behaviour is ruled by those traits (McRae 587-608):

"A junzi differs from other men in the way he preserves his heart. The junzi preserves his heart through humanity and through ritual. A humane man cherishes others and one who abides by ritual respects others. When one cherishes others, others can be counted on to cherish him; when one respects others, others can be counted on to respect him". (Eno, "Mencius" 84)

君子所以異於人者, 以其存心也。君子以仁存心, 以禮存心。仁者愛人, 有 禮者敬人。愛人者人恆愛之, 敬人者人恆敬之。(Mengzi IV.B.28)

Similarly to Confucius, Mencius also perceived serving one's parents and brothers as a root of $\mathrm{ren}^{6}$. It leads inevitably to stronger attachment to one's family than to other people, and is morally desirable, in Mencius' view. It also means that King Xuan's compassion for the ox is good, but misplaced (McRae 590):

"The junzi cherishes things but does not treat them with humanity. He treats people with humanity but not like parents. He loves his parents and treats people with humanity, treats people with humanity and cherishes creatures." (Eno, "Mencius" 132)

君子之於物也，愛之而弗仁；於民也，仁之而弗親。親親而仁民，仁民而愛 物. (Mengzi VII.A.45)

Mencian moral behaviour not only required deep understanding of oneself but also using all senses, sensitivity and creativity to deal with every situation in a different way. A sage, or a person who wants to become one, had to watch, to listen, to feel and to understand every person in every situation. Mencian ethics is a matter of character, not rules. Applying a good rule at the wrong time was an ethical error (Eno, "Mencius" 13). This is why another important skill required to be a sage or junzi was understanding that every situation is unique, the right time of applying different norms, the skill that Confucius himself possessed:

\footnotetext{
${ }^{6}$ 仁之實, 事親是也; 義之實, 從兄是也 (Mengzi IV.A.27).
} 
"When speed was appropriate he was fast, when delay was appropriate he was slow. Where it was appropriate to dwell apart he dwelt apart, where it was appropriate to serve he served." (Eno, "Mencius" 98)

[孔子] 可以速而速，可以久而久，可以處而處，可以仕而仕，孔子也 $[\cdots]$ 孔子，聖之時者也 (Mengzi V.B.10)

In Mencian thought walking a human way and realizing human moral nature is strongly connected to Heaven. The idea of human morality directly influencing sky/heaven and earth was also present in Zhongyong 中庸 and later became one of the most important ideas of Neo-Confucianism (lixue 理學):

"He who exhausts his mind knows his nature; to know one's nature is to know sky/heaven. The way to serve sky/heaven is to preserve the mind and nourish the nature." (Lau, trans., Mencius 144).

\section{盡其心者，知其性也。知其性，則知天矣 (Mengzi VII.A.1)}

Full realization and knowing one's nature is the final stage of selfdevelopment. Contrary to Confucius' morality of acquiring skill, Mencius' theory of human nature makes self-development out to require a preservation of vitality and integrity; then and only then may the fullness of one's dispositions and nature xing be displayed. As moral development was also a cultivation of the body's $q i$ 氣, vigor or energy, properly cultivated $q i$ became haoran zhi qi 浩然之氣, and enabled one's body to have a will ( $z h i$ 志) to follow his ren heart/mind, filling the cosmos:

[...] "What do you mean by 'flood-like qi?"”

"This is a $q i$ that is as vast and firm as can be. If one nurtures it by means of straightforward action and never impairs it, then it will fill all between sky/heaven and earth. It is a $q i$ that is a companion to righteousness and the Dao. Without these, it will starve away. It is generated through the long accumulation of acts of right. It is not something that can be seized through a single righteous act. If in your actions there is any sense of inadequacy in your heart, it will starve away. (Eno, "Mencius" 40)

“敢問何謂浩然之氣?”

其為氣也，至大至剛，以直養而無害，則塞于天地之閒。其為氣也，配義與 道; 無是，餒也。是集義所生者，非義襲而取之也。行有不慊於心，則餒矣

(Mengzi II.A.2)

The aim of this paper has been to analyse the process of constructing a moral person in the texts of the Analects and Mengzi from an emic per- 
spective. In early Confucian philosophy the moral agent is not an individual person with autonomy and rights, but rather an interdependent self with social roles incorporated in it. Both Confucius and Mencius sought not the universal but concentrated on the particular-concrete persons standing in the multiplicity of role relations with one another and virtuosity and productivity of the dynamic relations themselves (Ames and Rosemont 121). Using Mencius' vocabulary, the moral growth of a person is rooted in particular contexts. Being a human being is learning how to maintain proper relations and perfect one's moral character. It is quite clear, however, that "constructing a moral person" means developing moral qualities. Confucius claimed that those qualities are tied to ren relations, or ren behaviour. Mencius claimed that everyone has four dispositions which, if properly cultivated, will blossom into moral qualities - ren, yi, li, and zhi-governing human behaviour and attitudes toward others. In such a doctrine rules are used to cultivate moral qualities which, in time, will supersede rules and act according to one's moral judgement (Eno, "Mencius" 14).

\section{BIBLIOGRAPHY}

Ames, Roger, and Rosemont, Henry Jr. Confucian Role Ethics A Moral Vision for the 21st Century?. V\&R Academic, 2016.

Behuniak, James. Mencius on Becoming Human. University of Hawaii at Manoa, 2002.

Cua, Antonio S. "Xin and Moral Failure: Notes on an Aspects of Mencius Moral Psychology." Mencius Contexts and Interpretations, edited by Alan Kam-leung Chan. University of Hawaii Press, 2002.

Geaney, Jane. "Guarding Moral Boundaries: Shame in Early Confucianism." Philosophy East and West, vol. 54, no. 2, 2004, pp. 113-142, doi: 10.1353/pew.2004.0004.

Kieschnick, John. "Analects 12.1 and the Commentarial Tradition." Journal of the American Oriental Society, vol. 112, no 4, 1992, pp. 567-576, doi: 10.2307/604471

Lai, Karyn. "Confucian Moral Cultivation. Some Parallels with Musical Training." The Moral Circle and Self: Chinese and Western Approaches, edited by Kim-chong Chong, Sor-hoon Tan, and C.L. Ten. Carus Publishing, 2003, pp. 107-139.

Lai, Karyn. "Confucian Moral Thinking." Philosophy East and West, vol. 45, no. 2, 1995, pp. 249272, doi: $10.2307 / 1399567$.

Lai, Karyn. Learning form Chinese Philosophies: ethics of Independent and contextualised self. Ashgate Publishing Company \& Routledge, 2006.

Lai, Karyn. " $\mathrm{Li}$ in the Analects: Training In Moral Competence and the Question of flexibility." Philosophy East and West, vol. 56, no. 1, 2006, pp. 69-83, doi: 10.1353/pew.2006.0001.

Lau, D.C., trans. The Analects of Confucius. The Analects. Penguin Books, 1979.

Lau, D.C., trans. Mencius, revised edition, The Chinese University Press, 2003; first published 1970 by Penguin Books. 
Legge, James, trans. The Chinese Classics, vol. 1: Confucian Analects, The Great Learning and The Doctrine of the Mean. Clarendon Press, 1893.

McRae, Emily. "The Cultivation of Moral Feelings and Mengzi's Method of Extension." Philosophy East and West, vol. 61, no. 4, 2011, pp. 587-608, doi: 10.1353/pew.2011.0050.

Seok, Bongrae. Embodied Moral Psychology and Confucian Philosophy. Lanham: Lexington Books, 2013.

Quanxing, $\mathrm{Xu}$, and Huang Deyuan. "Theory on the Cultivation of Cognitive Subjects in Chinese Philosophy." Frontiers of Philosophy in China, vol. 3, no. 1, 2008, pp. 39-54, doi: 10.1007/ s11466-008-0003-0.

\section{INTERNET RESOURCES}

Chinese Text Project, www.ctext.org/confucianism. Accessed 13.01.2019.

Eno, Robert. "The Analects of Confucius. An Online Teaching Translation." 2012. Indiana University, Bloomington, www.indiana. edu/ p 374/Analects_of_Confucius_(Eno-2012).pdf. Accessed 24.03.2019.

Eno, Robert. "The Great Lerning and the Doctrine of Mean: An Online Teaching Translation." 2016. Indiana University, Bloomington, www.indiana.edu/ p374/Daxue-Zhongyong.pdf. Accessed 30.04.2019.

Eno, Robert. "Mencius: Translations, Notes and Commentary." 2016. Indiana University, Bloomington, www.indiana.edu/ p374/Mencius\%20(Eno-2016).pdf. Accessed 30.04.2019.

\section{BUDOWANIE OSOBY MORALNEJ \\ W ANALEKTACH 論語 I MENGZI 孟子}

\section{Streszczenie}

We wczesnej filozofii chińskiej koncepcja wyjątkowej jednostki oddzielonej od świata zewnętrznego nie ma ufundowania ontologicznego. Każda osoba jest otwartą, współzależną konstrukcją, której wyjątkowość można tylko osiągnąć, nie można jej darować. Osoba to nieokreślony zakres i miejsce doświadczeń, wyrażone poprzez określone role i relacje. W tym artykule jest analizowane rozumienie osoby w myśli konfucjańskiej i menciańskiej. Zgodnie z filozofią Konfucjusza junzi 君子 żyje w swoim statusie, dopóki utrzymuje relacje ren 仁 i wykazuje odpowiednie emocje związane z ren. Autorka twierdzi, że w Analektach ren jest pojęciem związanym z terminami shu 恕, zhong 忠, yi 義 i $l i$ 禮. Ren można interpretować jako idealną interakcję, która zaczyna się od zdecydowanej reakcji na drugiego człowieka. Reakcja empatyczna, wraz z zhong poczuciem obowiązku, jest podstawą do zastosowania sytuacyjnej normy moralnej yi i spełnienia jej zgodnie z li - normą społeczną. Zachowanie ren jest inne dla każdego człowieka w danej sytuacji. Trzeba się go nauczyć i praktykować w procesie samodoskonalenia, xiushen 修身.

Teoria moralna Mencjusza jest bardziej złożona i koncentruje się na ludzkiej naturze i jej cechach. Zgodnie z tym ludzką naturą jest shan 善, powszechnie thumaczone jako „to, co dobre”, ponieważ każda osoba ma cztery skłonności - emocje do rozwijania ren, yi, li i zhi 智. Ren może być uważane za cnotę - nie jest wrodzone, ale musi zostać osiągnięte i trzeba się go nauczyć. Inną umiejętnością wymaganą od mędrca było zrozumienie, że każda sytuacja jest wyjątkowa i że jest właściwy czas na zastosowanie różnych norm - shizhong 詩中. Myśl Mencjusza nie jest po prostu etyką cnoty - duże znaczenie mają w niej również czynniki sytuacyjne. Moralne zachowanie menciańskie jest złożone: nie tylko wymaga głębokiego zrozumienia siebie i drugiego, ale także wykorzystania wszystkich zmysłów, wrażliwości i kreatywności, aby poradzić sobie z każdą sytua- 
cją w inny sposób. Mędrzec lub osoba, która chce się nim stać, musi obserwować, słuchać, czuć i rozumieć każdą osobę i każdą sytuację. Kultywacja moralna w myśli Mengzi jest także kultywacją ciała $q i$ 氣 (wigoru lub energii). Właściwie kultywowana qi staje się haoran zhi qi 浩然之氣 (przepełniona qi) i pozwala ciału na $z h i$ 志 (wolę) podążania za swoim ren 仁 (sercem / umysłem).

Słowa kluczowe: fillozofia chińska; teoria moralna; etyka; zachowanie moralne; filozofia Konfucjusza; myśl Mencjusza. 